\title{
RESPON PERTUMBUHAN DAN PERKEMBANGAN SAYUR PELENG (Spinacia oleracea) TERHADAP PEMBERIAN PUPUK ORGANIK CAIR PADA BERBAGAI MULSA
}

\author{
Oleh: \\ Robert G. Marpaung ${ }^{1)}$ \\ Boy Pasaribu ${ }^{2}$ \\ Universitas Darma Agung, Medan 1,2) \\ E-mail: \\ marpaungpertanian@gmail.com ${ }^{1)}$ \\ boypasaribu@gmail.com ${ }^{2)}$
}

\begin{abstract}
This study aims at determing the response of growth and production of peleng vegetables to the application of liquid organic fertilizer in various mulch. The study was conducted on land located in Simalingkar A Medan with a height of $\pm 32 \mathrm{~m}$ above sea level, began from May to August 2017. The research method used a factorial randomized block design with 2 factors. The first factor is the dose of NASA liquid organic fertilizer $(\mathrm{P})$ which consists of 3 levels of treatment, namely: $\mathrm{P} 0=$ control, $\mathrm{P} 1=$ $3 \mathrm{ml} / 1$ water and P2 $=6 \mathrm{ml} / 1$ water. The second factor is the provision of mulch (M) which consists of three types, namely: M0: without mulching, M1: rice straw mulch and M2: black silver plastic mulch (MPHP). The results showed that the treatment of NASA liquid organic fertilizer up to $6 \mathrm{ml} / 1$ water significantly increased plant height, number of leaves, fresh weight of plants per sample, fresh weight of plants per plot, dry weight of plants per sample and dry weight of plants per plot, but differed not markedly on the relative growth rate of plants. The treatment of organic mulch and black silver mulch significantly increased plant height, number of leaves, fresh weight of plants per sample, fresh weight of plants per plot, dry weight of plants per sample and dry weight of plants per plot, but not significantly different to the relative growth rate of plants. The interaction between NASA's liquid organic fertilizer treatment and mulch administration had no significant effect on plant height, number of leaves, plant fresh weight per sample, plant fresh weight per plot, plant dry weight per sample, plant dry weight per plot and relative plant growth rate.
\end{abstract}

Keywords: liquid organic fertilizer, mulch and peleng

\section{ABSTRAK}

$32 \mathrm{~m}$ di atas permukaan laut, mulai dari Mei hingga Agustus 2017. Metode penelitian menggunakan rancangan acak kelompok faktorial dengan 2 faktor. Faktor pertama adalah dosis pupuk organik cair NASA (P) yang terdiri dari 3 level perlakuan, yaitu: P0 $=$ kontrol, $\mathrm{P} 1=3 \mathrm{ml} / 1$ air dan $\mathrm{P} 2=6 \mathrm{ml} / 1$ air. Faktor kedua adalah pemberian mulsa (M) yang terdiri dari tiga jenis, yaitu: M0: tanpa mulsa, M1: mulsa jerami padi dan M2: mulsa plastik perak hitam (MPHP). Hasil penelitian menunjukkan bahwa perlakuan pupuk organik cair NASA hingga $6 \mathrm{ml} / 1$ air secara signifikan meningkatkan tinggi tanaman, jumlah daun, berat segar tanaman per sampel, berat segar tanaman per plot, berat kering tanaman per sampel dan berat kering tanaman per sampel dan berat kering tanaman per plot, tetapi tidak berbeda nyata pada tingkat pertumbuhan relatif tanaman. Perlakuan mulsa organik dan mulsa perak hitam secara signifikan meningkatkan tinggi tanaman, jumlah daun, berat segar tanaman per sampel, berat segar tanaman per plot, 
berat kering tanaman per sampel dan berat kering tanaman per plot, tetapi tidak berbeda nyata. dengan tingkat pertumbuhan relatif tanaman. Interaksi antara perlakuan pupuk organik cair NASA dan administrasi mulsa tidak berpengaruh signifikan terhadap tinggi tanaman, jumlah daun, berat segar tanaman per sampel, berat segar tanaman per plot, berat kering tanaman per sampel, berat kering tanaman per sampel, bobot kering tanaman per plot dan pertumbuhan tanaman relatif menilai. \pm Penelitian ini bertujuan untuk mengetahui respon pertumbuhan dan produksi sayuran peleng terhadap aplikasi pupuk organik cair di berbagai mulsa. Penelitian dilakukan di tanah yang berlokasi di Simalingkar A Medan dengan ketinggian

Kata kunci: pupuk organik cair, mulsa dan peleng

\section{PENDAHULUAN}

Tanaman sayuran merupakan komoditi yang sebagian besar dikonsumsi dalam keadaan segar yang merupakan sumber vitamin dan mineral bagi manusia, bahkan beberapa diantaranya mengandung antioksidan yang dipercaya dapat menghambat sel kanker. Sayuran daun merupakan salah satu sumber vitamin dan mineral esensial yang sangat dibutuhkan oleh tubuh manusia, selain itu sayuran daun banyak mengandung serat. Serat bagi tubuh berfungsi membantu mempelancar pencernaan dan dapat mencegah kanker. Dari sekian banyak tanaman sayuran, tanaman peleng adalah salah satu yang menempati tempat istimewa karena kelezatannya, daunnya yang lembut dan bisa dimakan mentah dan dapat dijadikan salad (lalap) menambah minat konsumen untuk mengkonsumsinya dan oleh karenanya permintaan akan sayuran ini jadi terus meningkat. Peleng juga bisa diawetkan, dan dipasarkan dalam bentuk awetan maupun kalengan (Leafforlife.org., 2005).

Daun sayuran peleng yang lembut dan bergizi, baik mentah maupun dimasak, diakui mempunyai nilai tambah bagi diet manusia, karena peleng mengandung sejumlah besar mineral dan vitamin, khususnya vitamin A, kalsium, fosfor, besi dan kalium, peleng juga mengandung protein. Peleng dalam setiap $100 \mathrm{~g}$ mempunyai kandungan air $91 \%$, protein $32 \mathrm{~g}$, karbohidrat 4,3 g, dan lemak 0,3 g (Uga.edu., 2005).

Pada budidaya tanaman sayuran, masalah yang sering dihadapi adalah rendahnya kesuburan tanah. Media tanah untuk tanaman sayuran harus mengandung bahan organik yang cukup tinggi. Sehingga pada budidaya tanaman sayuran penggunaan pupuk organik sudah merupakan keharusan karena keberhasilan tanaman sayuran sangat dipengaruhi oleh kualitas dan jumlah bahan organik yang diberikan ke dalam tanah (Hakim dkk., 2005).

$$
\text { Penggunaan pupuk organik }
$$

mampu menjadi solusi dalam mengurangi aplikasi pupuk anorganik yang berlebihan dikarenakan adanya bahan organik yang mampu memperbaiki sifat fisika, kimia, dan biologi tanah. Perbaikan terhadap sifat fisik yaitu menggemburkan tanah, memperbaiki aerasi dan drainase, meningkatkan ikatan antar partikel, meningkatkan kapasitas menahan air, mencegah erosi dan longsor, dan merevitalisasi daya olah tanah. Fungsi pupuk organik terhadap sifat kimia yaitu meningkatkan kapasitas tukar kation, meningkatkan ketersediaan unsur hara, dan meningkatkan proses pelapukan bahan mineral. Adapun terhadap sifat biologi yaitu menjadikan sumber makanan bagi mikroorganisme tanah seperti fungi, bakteri, serta mikroorganisme menguntungkan lainnya, sehingga perkembangannya 
menjadi lebih cepat. Pupuk organik disamping dapat menyuplai hara NPK, juga dapat menyediakan unsur hara mikro sehingga dapat mencegah kahat unsur mikro pada tanah marginal atau tanah yang telah diusahakan secara intensif dengan pemupukan yang kurang seimbang (Hadisuwito, 2008).

Semakin tingginya aplikasi pupuk anorganik tanpa pengembalian bahan organik ke tanah mengakibatkan keseimbangan dan ketersediaan hara tanah terganggu. Tingginya harga pupuk dengan ketersediaan yang terbatas dan efisiensi pemupukan yang rendah mengakibatkan pemupukan tidak lagi nyata meningkatkan hasil. Pupuk organik cair merupakan salah satu alternatif untuk meningkatkan ketersediaan, kecukupan, dan efisiensi serapan hara bagi tanaman.

Penggunaan pupuk organik cair diharapkan akan memberikan kontribusi yang besar. Kontribusi ini dimaksudkan dalam mendukung upaya penerapan pertanian organik. Banyak pihak menganggap bahwa persoalan pertanian organik terletak pada bahan baku yang kurang tersedia.

Upaya dalam merekayasa iklim mikro untuk mencapai pertumbuhan optimum tanaman merupakan salah satu ciri pertanian modern. Pada lingkungan dengan curah hujan tinggi sebagian besar petani melakukan usaha budidaya di lingkungan terbuka, akibatnya saat musim hujan banyak tanaman yang rusak karena terpukul air hujan dan terserang penyakit. Masalah ini dapat diminimalkan dengan penggunaan mulsa. Penggunaan mulsa bertujuan untuk mencegah kehilangan air dari tanah sehingga kehilangan air dapat dikurangi dengan memelihara temperatur dan kelembaban tanah. Aplikasi mulsa merupakan salah satu upaya menekan pertumbuhan gulma, memodifikasi keseimbangan air, suhu dan kelembaban tanah serta menciptakan kondisi yang sesuai bagi tanaman, sehingga tanaman dapat tumbuh dan berkembang dengan baik (Mulyatri, 2003).

Maka penulis mencoba mengaplikasikannya di lapangan dengan melakukan penelitian tentang "Respon Pertumbuhan dan Produksi Sayur Peleng (Spinacia oleracea) terhadap Pemberian Pupuk Organik Cair pada Berbagai Mulsa”.

\section{Tujuan Penelitian}

Tujuan penelitian ini adalah untuk mengetahui respon pertumbuhan dan produksi sayur peleng (Spinacia oleracea) terhadap pemberian pupuk organik cair pada berbagai mulsa.

\section{METODE PELAKSANAAN}

Penelitian dilaksanakan di lahan petani yang terletak di Desa Simalingkar A, Medan dengan ketinggian tempat $\pm 32 \mathrm{~m}$ di atas permukaan laut, yang dimulai dari bulan Mei hingga bulan Agustus 2017.

Metode penelitin ini menggunakan rancangan acak kelompok (RAK) faktorial dengan 2 faktor. Faktor pertama adalah dosis pupuk organik cair NASA (P) yang terdiri dari 3 taraf perlakuan yaitu : $\mathrm{P}_{0}$ $=$ kontrol, $\mathrm{P}_{1}=3 \mathrm{ml} / \mathrm{l}$ air dan $\mathrm{P}_{2}=6$ $\mathrm{ml} / \mathrm{l}$ air. Faktor kedua adalah pemberian mulsa $(\mathrm{M})$ yang terdiri dari tiga jenis, yaitu : $\mathbf{M}_{0}:$ tanpa pemberian mulsa, $\mathrm{M}_{1}$ : pemberian mulsa jerami padi dan $\mathbf{M}_{2}$ : pemberian mulsa plastik hitam perak (MPHP). Parameter yang diamati adalah tinggi tanaman, jumlah daun, bobot segar tanaman per sampel, bobot segar tanaman per plot, bobot kering tanaman per sampel, bobot kering tanaman per plot dan laju tumbuh relatif.

\section{HASIL dan PEMBAHASAN Tinggi Tanaman (cm)}


Rataan tinggi tanaman peleng pada umur 3, 4, 5, 6 dan 7 mst akibat perlakuan pupuk organik cair NASA

Tabel 1. Rataan Tinggi Tanaman $(\mathrm{cm})$ akibat Perlakuan Pupuk Organik Cair NASA dan Pemberian Mulsa pada Umur 3, 4, 5, 6 dan 7 Minggu Setelah Tanam

\begin{tabular}{cccccc}
\hline \multirow{2}{*}{ Perlakuan } & \multicolumn{5}{c}{ Tinggi Tanaman $(\mathrm{cm})$} \\
\cline { 2 - 6 } & $3 \mathrm{mst}$ & $4 \mathrm{mst}$ & $5 \mathrm{mst}$ & $6 \mathrm{mst}$ & $7 \mathrm{mst}$ \\
\hline $\mathrm{P}_{0}$ & $3.50 \mathrm{a}$ & $4.67 \mathrm{a}$ & $8.23 \mathrm{a}$ & $12.40 \mathrm{a}$ & $18.37 \mathrm{a}$ \\
$\mathrm{P}_{1}$ & $3.65 \mathrm{~b}$ & $4.90 \mathrm{~b}$ & $8.77 \mathrm{~b}$ & $13.49 \mathrm{~b}$ & $19.73 \mathrm{~b}$ \\
$\mathrm{P}_{2}$ & $3.74 \mathrm{c}$ & $5.01 \mathrm{c}$ & $8.94 \mathrm{c}$ & $14.18 \mathrm{c}$ & $20.50 \mathrm{c}$ \\
\hline $\mathrm{M}_{0}$ & $3.39 \mathrm{a}$ & $4.55 \mathrm{a}$ & $7.44 \mathrm{a}$ & $11.00 \mathrm{a}$ & $15.64 \mathrm{a}$ \\
$\mathrm{M}_{1}$ & $3.63 \mathrm{~b}$ & $4.89 \mathrm{~b}$ & $9.08 \mathrm{~b}$ & $14.15 \mathrm{~b}$ & $20.77 \mathrm{~b}$ \\
$\mathrm{M}_{2}$ & $3.88 \mathrm{c}$ & $5.15 \mathrm{c}$ & $9.42 \mathrm{~b}$ & $14.92 \mathrm{c}$ & $22.19 \mathrm{c}$ \\
\hline
\end{tabular}

Keterangan: Angka yang diikuti oleh huruf yang sama dalam kolom perlakuan yang sama tidak berbeda nyata pada uji Duncan taraf uji 5\%

Hubungan antara pupuk organik cair NASA dengan tinggi tanaman peleng pada umur 7 mst, diperlihatkan pada Gambar 3.

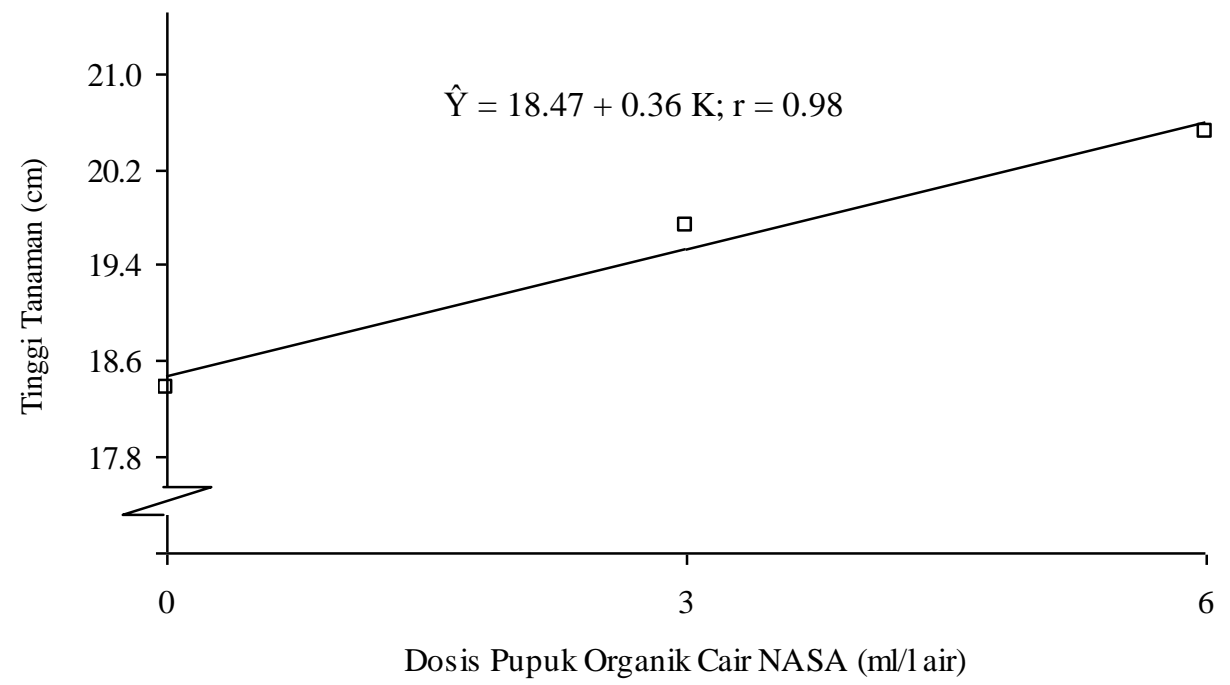

Gambar 1. Kurva Respon Pengaruh Pupuk Organik Cair NASA terhadap Tinggi Tanaman Peleng pada Umur 7 Minggu Setelah Tanam

Dari Gambar 1 terlihat bahwa semakin tinggi pupuk organik cair NASA maka tinggi tanaman peleng semakin meningkat mengikuti kurva regresi linier positif dengan nilai $r$ sebesar 0.98. Hal ini berarti bahwa jika dosis pupuk organik cair NASA meningkat $1 \mathrm{ml} / \mathrm{l}$ air maka tinggi tanaman meningkat sebesar $0.36 \mathrm{~cm}$.

Hubungan antara pemberian mulsa dengan tinggi tanaman peleng pada umur $7 \mathrm{mst}$, diperlihatkan pada Gambar 2. 


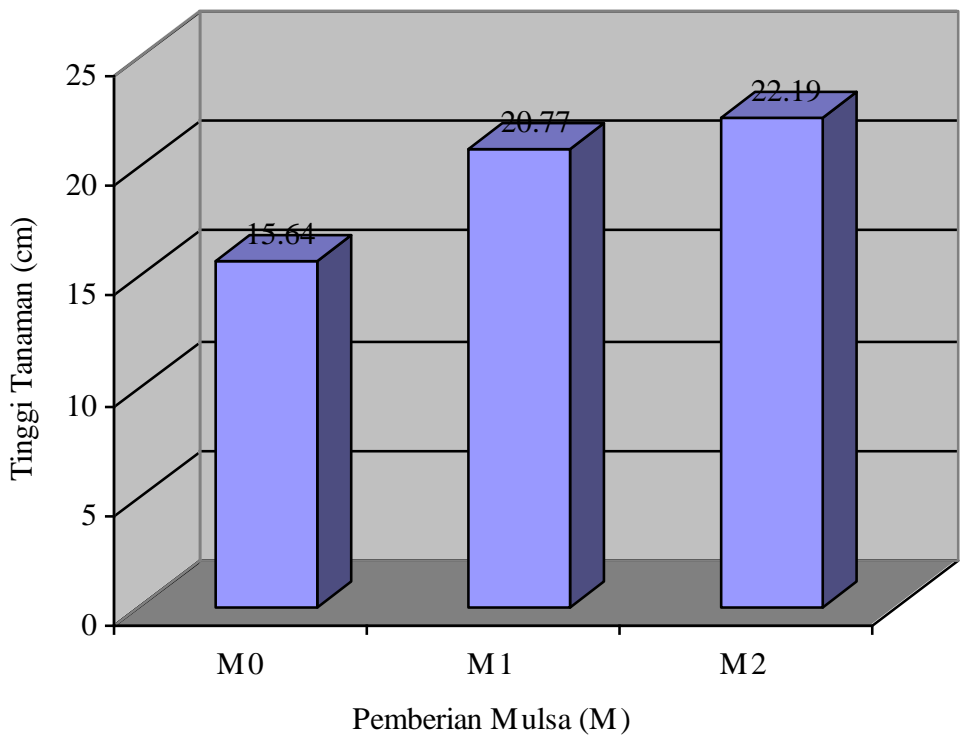

Gambar 2. Histogram Respon Pengaruh Pemberian Mulsa terhadap Tinggi Tanaman Peleng pada Umur 7 Minggu Setelah Tanam

Dari Gambar 2 terlihat bahwa dengan pemberian mulsa $\left(\mathrm{M}_{1}\right.$ dan $\left.\mathrm{M}_{2}\right)$ pertumbuhan tinggi tanaman lebih tinggi dibandingkan tanpa pemberian mulsa $\left(\mathrm{M}_{0}\right)$.

\section{Jumlah Daun (helai)}

Rataan jumlah daun tanaman peleng pada umur 3, 4, 5, 6 dan $7 \mathrm{mst}$ akibat perlakuan pupuk organik cair NASA dan pemberian mulsa disajikan pada Tabel 2.

Tabel 2. Rataan Jumlah Daun Tanaman (helai) akibat Perlakuan Pupuk Organik Cair NASA dan Pemberian Mulsa pada Umur 3, 4, 5, 6 dan 7 Minggu Setelah Tanam

\begin{tabular}{cccccc}
\hline \multirow{2}{*}{ Perlakuan } & \multicolumn{5}{c}{ Jumlah Daun (helai) } \\
\cline { 2 - 6 } & $3 \mathrm{mst}$ & $4 \mathrm{mst}$ & $5 \mathrm{mst}$ & $6 \mathrm{mst}$ & $7 \mathrm{mst}$ \\
\hline $\mathrm{P}_{0}$ & $3.00 \mathrm{a}$ & $4.67 \mathrm{a}$ & $6.56 \mathrm{a}$ & $9.04 \mathrm{a}$ & $12.41 \mathrm{a}$ \\
$\mathrm{P}_{1}$ & $3.44 \mathrm{~b}$ & $5.44 \mathrm{~b}$ & $7.33 \mathrm{~b}$ & $9.85 \mathrm{~b}$ & $13.52 \mathrm{~b}$ \\
$\mathrm{P}_{2}$ & $3.56 \mathrm{~b}$ & $5.59 \mathrm{~b}$ & $7.59 \mathrm{c}$ & $10.67 \mathrm{c}$ & $14.67 \mathrm{c}$ \\
\hline $\mathrm{M}_{0}$ & $3.11 \mathrm{a}$ & $4.67 \mathrm{a}$ & $6.59 \mathrm{a}$ & $8.63 \mathrm{a}$ & $11.96 \mathrm{a}$ \\
$\mathrm{M}_{1}$ & $3.37 \mathrm{~b}$ & $5.33 \mathrm{~b}$ & $7.19 \mathrm{~b}$ & $10.26 \mathrm{~b}$ & $13.93 \mathrm{~b}$ \\
$\mathrm{M}_{2}$ & $3.52 \mathrm{~b}$ & $5.70 \mathrm{c}$ & $7.70 \mathrm{c}$ & $10.67 \mathrm{~b}$ & $14.70 \mathrm{c}$ \\
\hline
\end{tabular}

Keterangan: Angka yang diikuti oleh huruf yang sama dalam kolom perlakuan yang sama tidak berbeda nyata pada uji Duncan taraf uji 5\%

Hubungan antara pupuk organik cair NASA dengan jumlah daun tanaman peleng pada umur $7 \mathrm{mst}$, diperlihatkan pada Gambar 3. 


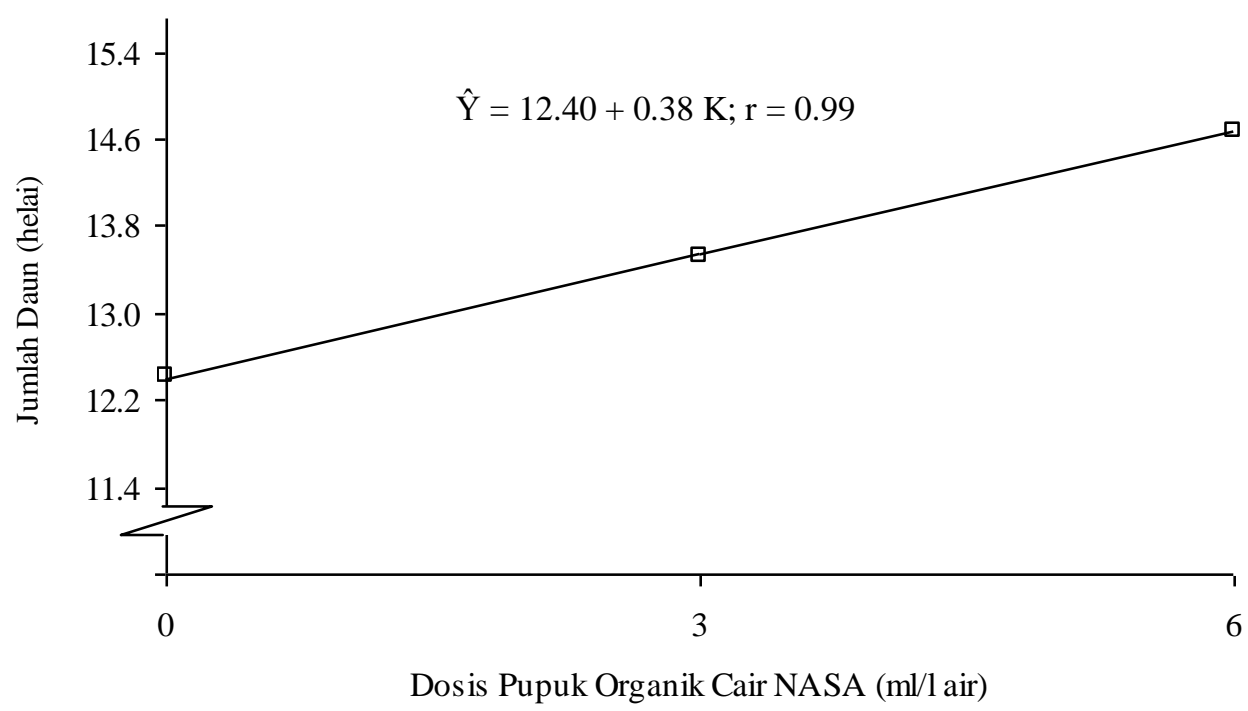

Gambar 3. Kurva Respon Pengaruh Pupuk Organik Cair NASA terhadap Jumlah Daun Tanaman Peleng pada Umur 7 Minggu Setelah Tanam

Dari Gambar 3 terlihat bahwa semakin tinggi pupuk organik cair NASA maka jumlah daun tanaman peleng semakin meningkat mengikuti kurva regresi linier positif dengan nilai r sebesar 0.99. Hal ini berarti bahwa jika dosis pupuk organik cair NASA meningkat $1 \mathrm{ml} / \mathrm{l}$ air maka jumlah daun tanaman meningkat sebesar $0.38 \mathrm{~cm}$.

Hubungan antara pemberian mulsa dengan jumlah daun tanaman peleng pada umur $7 \mathrm{mst}$, diperlihatkan pada Gambar 4.

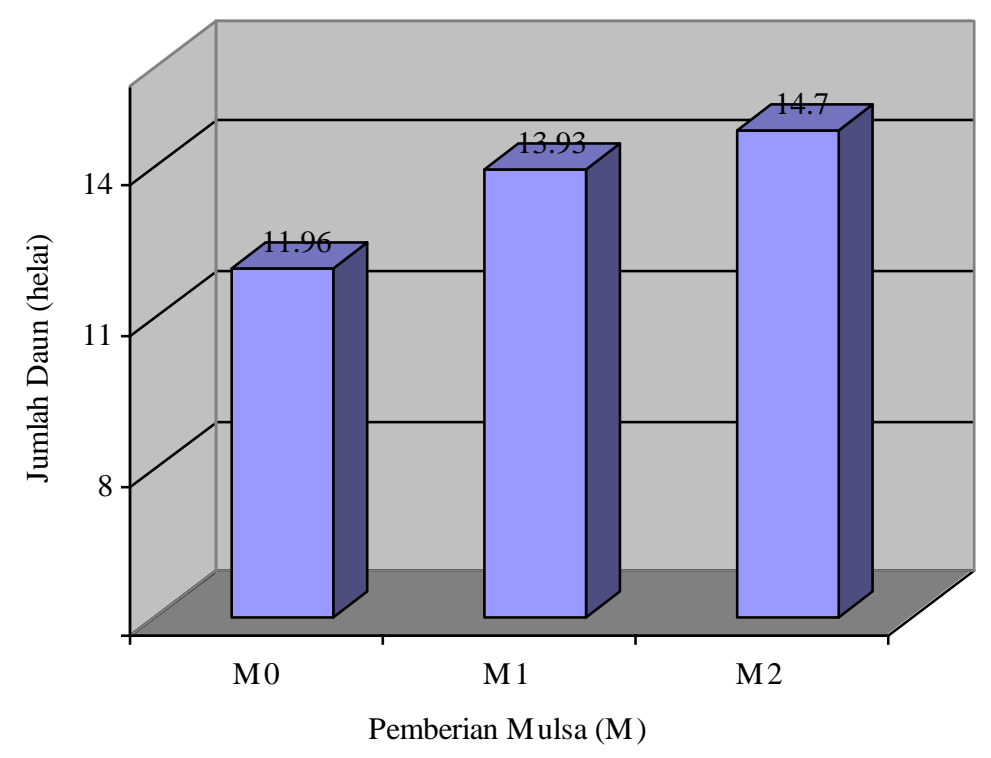

Gambar 4. Histogram Respon Pengaruh Pemberian Mulsa terhadap Jumlah Daun Tanaman Peleng pada Umur 7 Minggu Setelah Tanam 
Dari Gambar 4 terlihat bahwa dengan pemberian mulsa $\left(\mathrm{M}_{1}\right.$ dan $\left.\mathrm{M}_{2}\right)$ pertumbuhan jumlah daun tanaman lebih banyak dibandingkan tanpa pemberian mulsa $\left(\mathrm{M}_{0}\right)$.
Bobot Segar Tanaman per Sampel

Rataan bobot segar per sampel akibat perlakuan pupuk organik cair NASA dan pemberian mulsa disajikan pada Tabel 3.

Tabel 3. Rataan Bobot Segar Tanaman per Sampel (g) akibat Perlakuan Pupuk Organik Cair NASA dan Pemberian Mulsa

\begin{tabular}{ccccc}
\hline Perlakuan & $\mathrm{M}_{0}$ & $\mathrm{M}_{1}$ & $\mathrm{M}_{2}$ & Rataan \\
\hline $\mathrm{P}_{0}$ & 739.33 & 846.67 & 898.67 & $828.22 \mathrm{a}$ \\
$\mathrm{P}_{1}$ & 774.67 & 888.00 & 942.00 & $868.22 \mathrm{~b}$ \\
$\mathrm{P}_{2}$ & 826.67 & 919.33 & 970.00 & $905.33 \mathrm{c}$ \\
\hline Rataan & $780.22 \mathrm{a}$ & $884.67 \mathrm{~b}$ & $936.89 \mathrm{c}$ & \\
\hline
\end{tabular}

Keterangan: Angka yang diikuti oleh huruf yang sama dalam kolom dan baris perlakuan yang sama tidak berbeda nyata pada uji Duncan taraf uji 5\%

Hubungan antara pupuk organik cair NASA dengan bobot segar tanaman per sampel diperlihatkan pada Gambar 5.

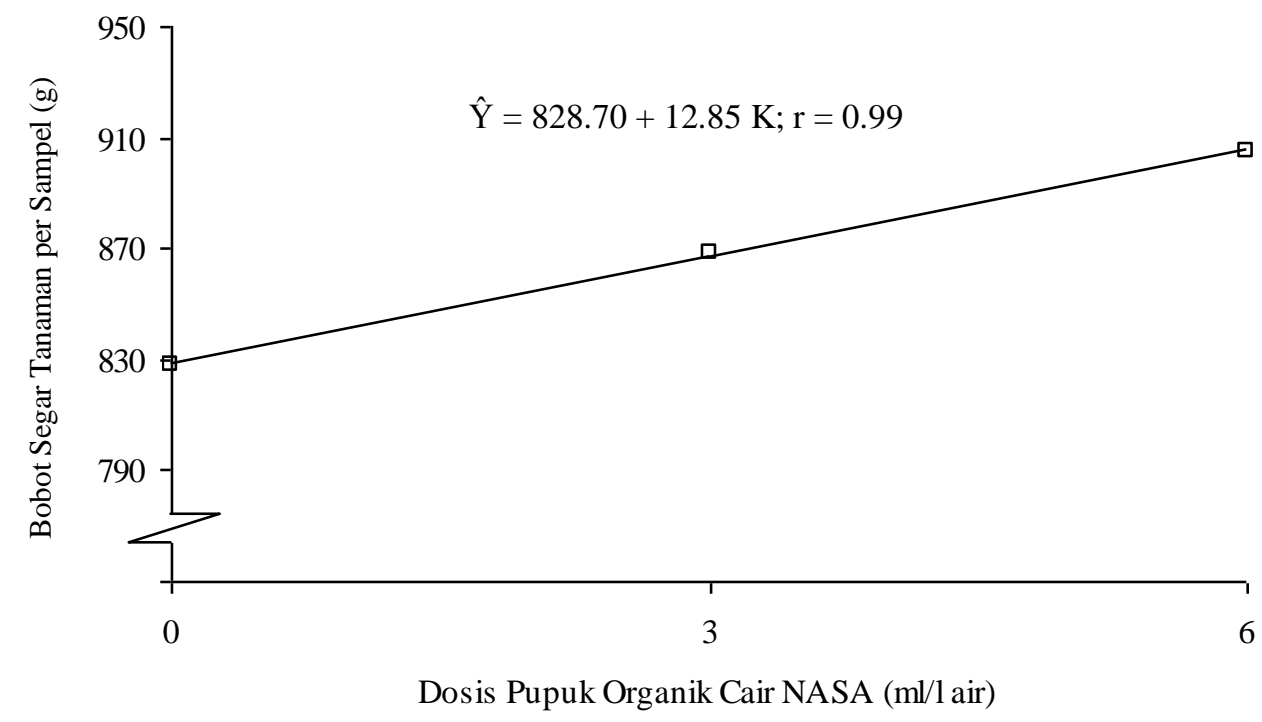

Gambar 5. Kurva Respon Pengaruh Pupuk Organik Cair NASA terhadap Bobot Segar Tanaman per Sampel

Dari Gambar 5 terlihat bahwa semakin tinggi pupuk organik cair NASA maka bobot segar tanaman per sampel semakin meningkat mengikuti kurva regresi linier positif dengan nilai $r$ sebesar 0.99. Hal ini berarti bahwa jika dosis pupuk organik cair NASA meningkat $1 \mathrm{ml} / \mathrm{l}$ air maka bobot segar tanaman per sampel meningkat sebesar $12.85 \mathrm{~g}$. 
Hubungan antara pemberian mulsa dengan bobot segar tanaman per sampel diperlihatkan pada Gambar 6.

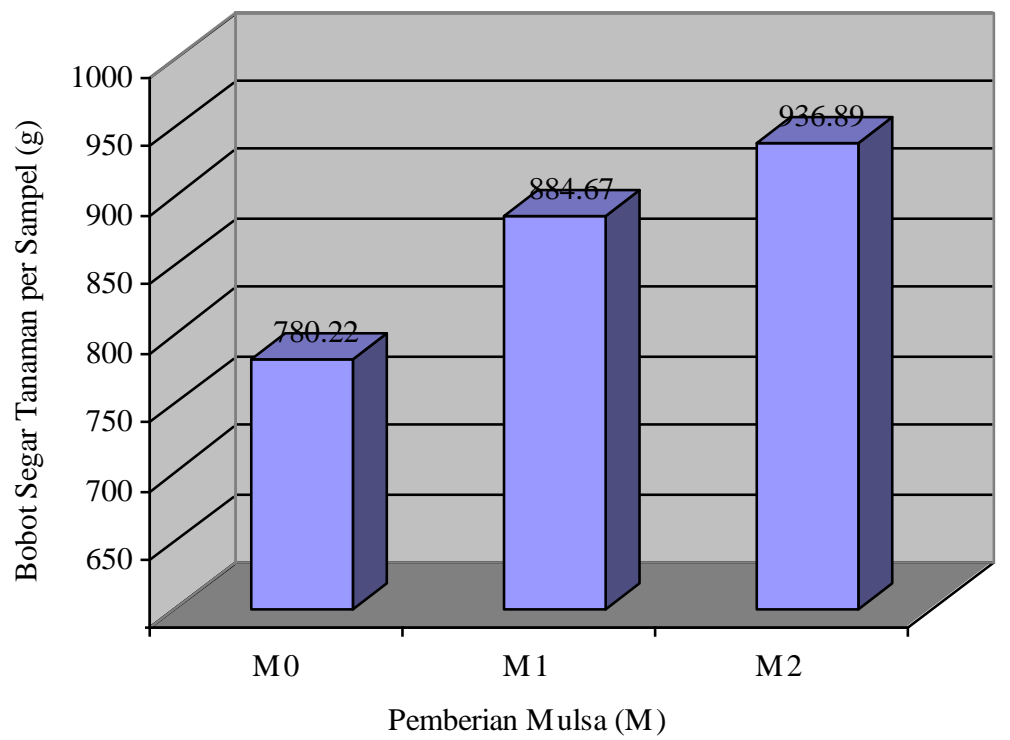

Gambar 6. Histogram Respon Pengaruh Pemberian Mulsa terhadap Bobot Segar Tanaman per Sampel

Dari Gambar 6 terlihat bahwa dengan pemberian mulsa $\left(\mathrm{M}_{1}\right.$ dan $\left.\mathrm{M}_{2}\right)$ bobot segar tanaman per sampel lebih berat dibandingkan tanpa mulsa $\left(\mathrm{M}_{0}\right)$.

\section{Bobot Segar Tanaman per Plot}

Rataan bobot segar per plot akibat perlakuan pupuk organik cair NASA dan pemberian mulsa disajikan pada Tabel 4.

Tabel 4. Rataan Bobot Segar Tanaman per Plot (kg) akibat Perlakuan Pupuk Organik Cair NASA dan Pemberian Mulsa

\begin{tabular}{ccccc}
\hline Perlakuan & $\mathrm{M}_{0}$ & $\mathrm{M}_{1}$ & $\mathrm{M}_{2}$ & Rataan \\
\hline $\mathrm{P}_{0}$ & 7.23 & 8.17 & 8.83 & $8.08 \mathrm{a}$ \\
$\mathrm{P}_{1}$ & 7.70 & 8.50 & 9.40 & $8.53 \mathrm{~b}$ \\
$\mathrm{P}_{2}$ & 8.23 & 9.17 & 9.67 & $9.02 \mathrm{c}$ \\
\hline Rataan & $7.72 \mathrm{a}$ & $8.61 \mathrm{~b}$ & $9.30 \mathrm{c}$ & \\
\hline
\end{tabular}

Keterangan: Angka yang diikuti oleh huruf yang sama dalam kolom dan baris perlakuan yang sama tidak berbeda nyata pada uji Duncan taraf uji 5\%

Tabel 4 menunjukkan bahwa pada perlakuan pupuk organik cair NASA, bobot segar tanaman per plot terberat terdapat pada taraf $\mathrm{P}_{3}$ berbeda nyata dengan $\mathrm{P}_{1}$ dan $\mathrm{P}_{2}$. Bobot segar tanaman per plot pada perlakuan $\mathrm{P}_{2}$ berbeda nyata dengan $\mathrm{P}_{1}$.
Tabel 4 juga menunjukkan bahwa pada perlakuan pemberian mulsa, bobot segar tanaman per plot terdapat pada taraf $\mathrm{M}_{2}$ berbeda nyata dengan $\mathrm{M}_{0}$ dan $\mathrm{M}_{1}$. Bobot segar tanaman per plot pada perlakuan $\mathrm{M}_{1}$ berbeda nyata dengan $\mathrm{M}_{0}$. 
Hubungan antara pupuk organik cair NASA dengan bobot segar tanaman per plot diperlihatkan pada Gambar 7.

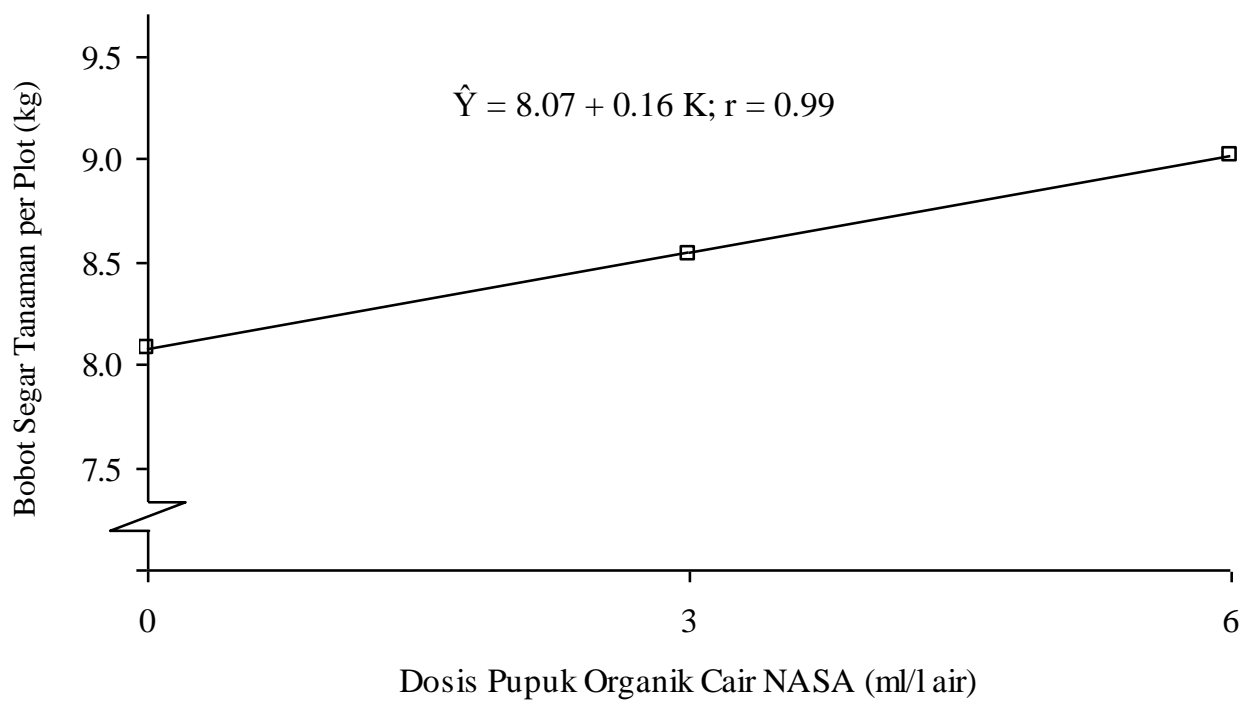

Gambar 7. Kurva Respon Pengaruh Pupuk Organik Cair NASA terhadap Bobot Segar Tanaman per Plot

Dari Gambar 7 terlihat bahwa semakin tinggi pupuk organik cair NASA maka bobot segar tanaman per plot semakin meningkat mengikuti kurva regresi linier positif dengan nilai $r$ sebesar 0.99 .
Hal ini berarti bahwa jika dosis pupuk organik cair NASA meningkat $1 \mathrm{ml} / \mathrm{l}$ air maka bobot segar tanaman per plot meningkat sebesar $0.16 \mathrm{~kg}$.

Hubungan antara pemberian mulsa dengan bobot segar tanaman per plot diperlihatkan pada Gambar 8 .

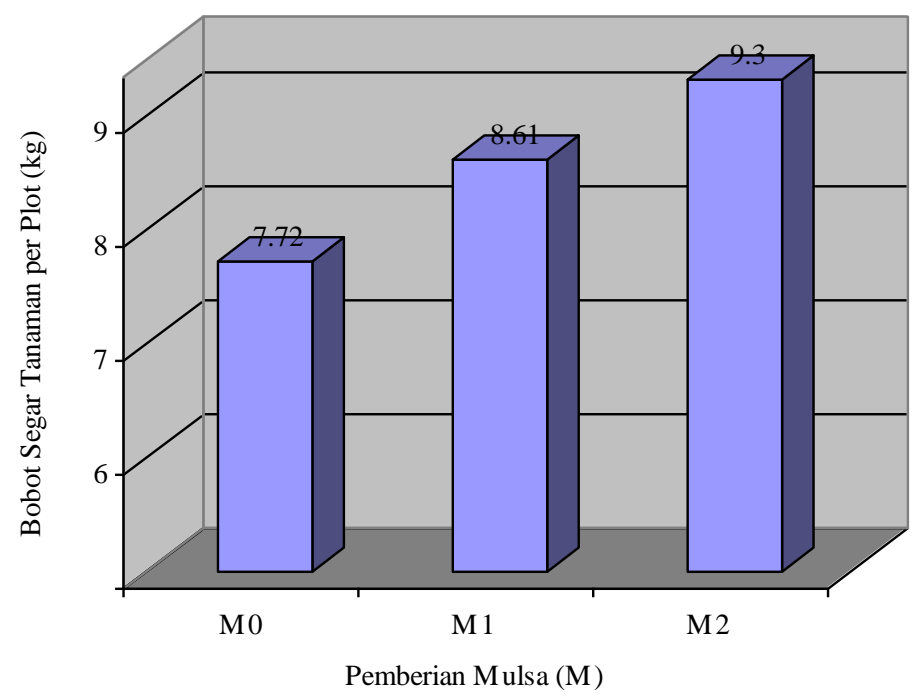

Gambar 8. Histogram Respon Pengaruh Pemberian Mulsa terhadap Bobot Segar Tanaman per Plot 
Dari Gambar 8 terlihat bahwa dengan pemberian mulsa $\left(\mathrm{M}_{1}\right.$ dan $\left.\mathrm{M}_{2}\right)$ bobot segar tanaman per sampel lebih berat dibandingkan tanpa mulsa $\left(\mathrm{M}_{0}\right)$.
Bobot Kering Tanaman per Sampel

Rataan bobot kering per sampel akibat perlakuan pupuk organik cair NASA dan pemberian mulsa disajikan pada Tabel 5.

Tabel 5. Rataan Bobot Kering Tanaman per Sampel (g) akibat Perlakuan Pupuk Organik Cair NASA dan Pemberian Mulsa

\begin{tabular}{ccccc}
\hline Perlakuan & $\mathrm{M}_{0}$ & $\mathrm{M}_{1}$ & $\mathrm{M}_{2}$ & Rataan \\
\hline $\mathrm{P}_{0}$ & 144.00 & 165.67 & 179.00 & $162.89 \mathrm{a}$ \\
$\mathrm{P}_{1}$ & 153.67 & 167.67 & 188.00 & $169.78 \mathrm{~b}$ \\
$\mathrm{P}_{2}$ & 164.00 & 183.33 & 193.33 & $180.22 \mathrm{c}$ \\
\hline Rataan & $153.89 \mathrm{a}$ & $172.22 \mathrm{~b}$ & $186.78 \mathrm{c}$ & \\
\hline
\end{tabular}

Keterangan: Angka yang diikuti oleh huruf yang sama dalam kolom dan baris perlakuan yang sama tidak berbeda nyata pada uji Duncan taraf uji 5\%

Tabel 5 menunjukkan bahwa pada perlakuan pupuk organik cair NASA, bobot kering tanaman per sampel terberat terdapat pada taraf $\mathrm{P}_{3}$ berbeda nyata dengan $\mathrm{P}_{1}$ dan $\mathrm{P}_{2}$.

Tabel 5 juga menunjukkan bahwa pada perlakuan pemberian mulsa, bobot kering tanaman per sampel terdapat pada taraf $\mathrm{M}_{2}$ berbeda nyata dengan $\mathrm{M}_{0}$ dan $\mathrm{M}_{1}$. Bobot kering tanaman pada perlakuan $\mathrm{M}_{1}$ berbeda nyata dengan $\mathrm{M}_{0}$.

Hubungan antara pupuk organik cair NASA dengan bobot kering tanaman per sampel diperlihatkan pada Gambar 9.

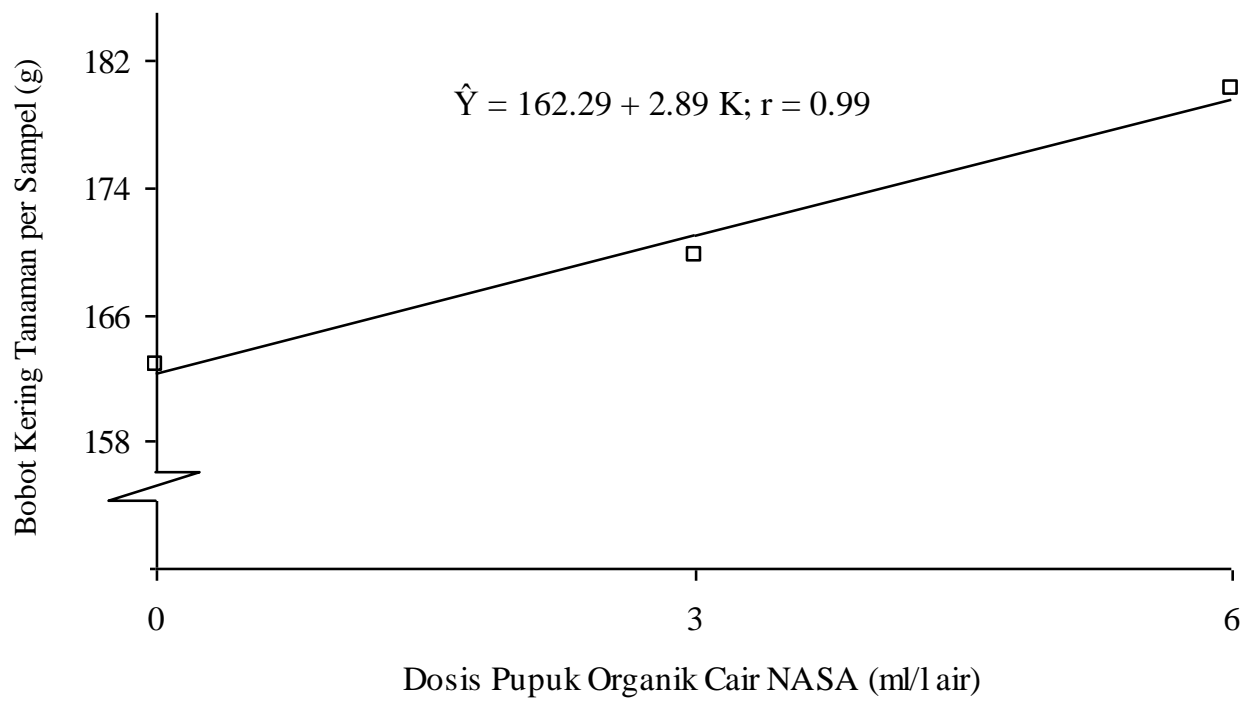

Gambar 9. Kurva Respon Pengaruh Pupuk Organik Cair NASA terhadap Bobot Kering Tanaman per Sampel 
Dari Gambar 9 terlihat bahwa semakin tinggi pupuk organik cair NASA maka bobot kering tanaman per sampel semakin meningkat mengikuti kurva regresi linier positif dengan nilai $r$

Hubungan antara pemberian mulsa dengan bobot segar tanaman per sampel diperlihatkan pada Gambar 10.

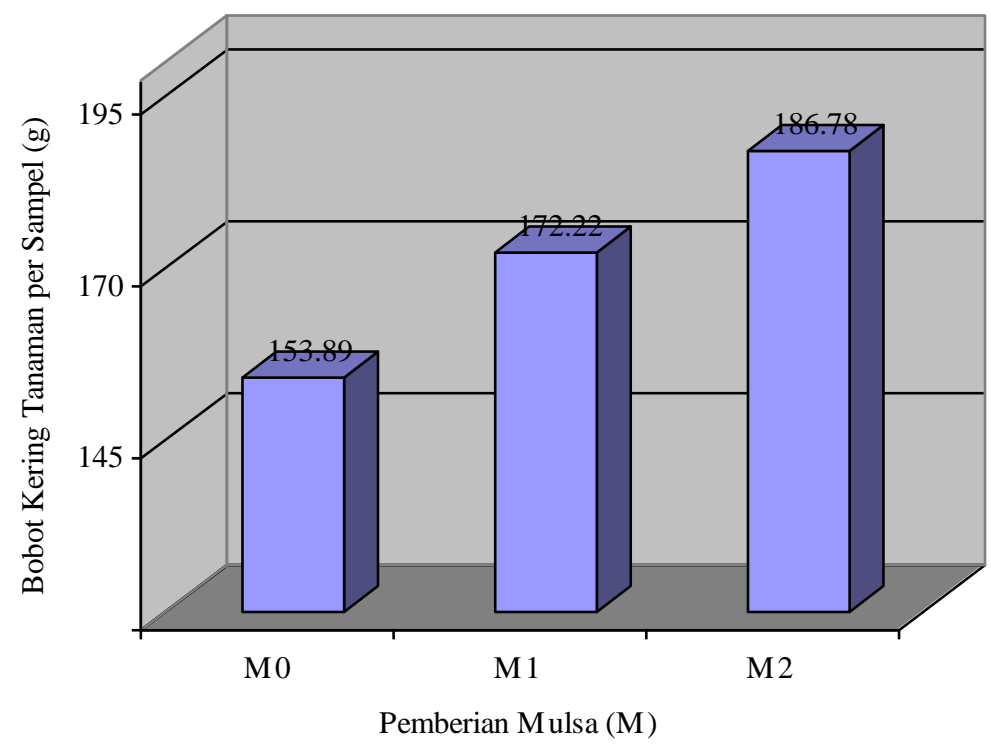

Gambar 10. Histogram Respon Pengaruh Pemberian Mulsa terhadap Bobot Kering Tanaman per Sampel

Dari Gambar 10 terlihat bahwa dengan pemberian mulsa $\left(\mathrm{M}_{1}\right.$ dan $\left.\mathrm{M}_{2}\right)$ bobot kering tanaman per sampel lebih berat dibandingkan tanpa mulsa $\left(\mathrm{M}_{0}\right)$.

Tabel 6. Rataan Bobot Kering Tanaman per Plot (kg) akibat Perlakuan Pupuk Organik Cair NASA dan Pemberian Mulsa

\begin{tabular}{ccccc}
\hline Perlakuan & $\mathrm{M}_{0}$ & $\mathrm{M}_{1}$ & $\mathrm{M}_{2}$ & Rataan \\
\hline $\mathrm{P}_{0}$ & 1.50 & 1.67 & 1.87 & $1.68 \mathrm{a}$ \\
$\mathrm{P}_{1}$ & 1.63 & 1.83 & 2.10 & $1.86 \mathrm{~b}$ \\
$\mathrm{P}_{2}$ & 1.70 & 2.00 & 2.13 & $1.94 \mathrm{c}$ \\
\hline Rataan & $1.61 \mathrm{a}$ & $1.83 \mathrm{~b}$ & $2.03 \mathrm{c}$ & \\
\hline
\end{tabular}

Keterangan: Angka yang diikuti oleh huruf yang sama dalam kolom dan baris perlakuan yang sama tidak berbeda nyata pada uji Duncan taraf uji 5\%

Tabel 6 menunjukkan bahwa pada perlakuan pupuk organik cair NASA, bobot kering tanaman per plot terberat terdapat pada taraf $\mathrm{P}_{3}$ berbeda nyata dengan $\mathrm{P}_{1}$ dan $\mathrm{P}_{2}$. Bobot kering tanaman per plot pada perlakuan $\mathrm{P}_{2}$ berbeda nyata dengan $\mathrm{P}_{1}$.

Tabel 6 juga menunjukkan bahwa pada perlakuan pemberian mulsa, bobot kering tanaman per plot 
terdapat pada taraf $\mathrm{M}_{3}$ berbeda nyata tanaman per plot pada perlakuan $\mathbf{M}_{1}$ dengan $\mathbf{M}_{1}$ dan $\mathbf{M}_{2}$. Bobot kering berbeda nyata dengan $\mathbf{M}_{0}$.

Hubungan antara pupuk organik cair NASA dengan bobot kering tanaman per plot diperlihatkan pada Gambar 11.

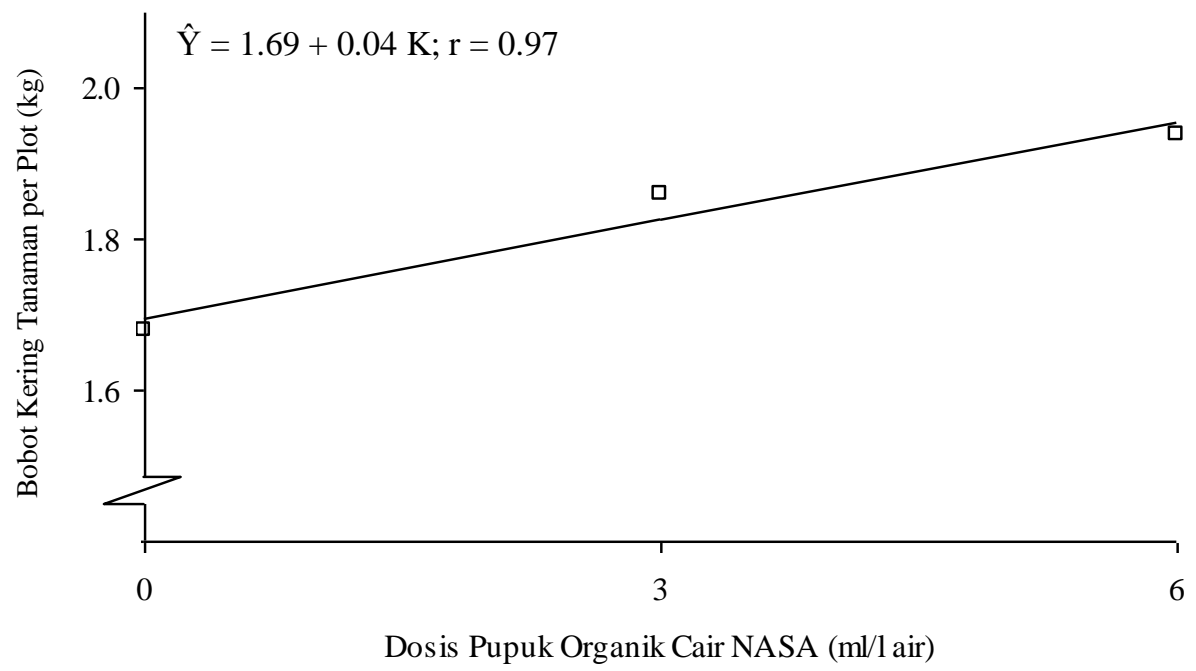

Gambar 11. Kurva Respon Pengaruh Pupuk Organik Cair NASA terhadap Bobot Kering Tanaman per Plot

Dari Gambar 11 terlihat bahwa semakin tinggi pupuk organik cair NASA maka bobot kering tanaman per plot semakin meningkat mengikuti kurva regresi linier positif dengan nilai $r$ sebesar 0.97 .
Hal ini berarti bahwa jika dosis pupuk organik cair NASA meningkat $1 \mathrm{ml} / \mathrm{l}$ air maka bobot kering tanaman per plot meningkat sebesar $0.04 \quad \mathrm{~kg}$.

Hubungan antara pemberian mulsa dengan bobot kering tanaman per plot diperlihatkan pada Gambar 12.

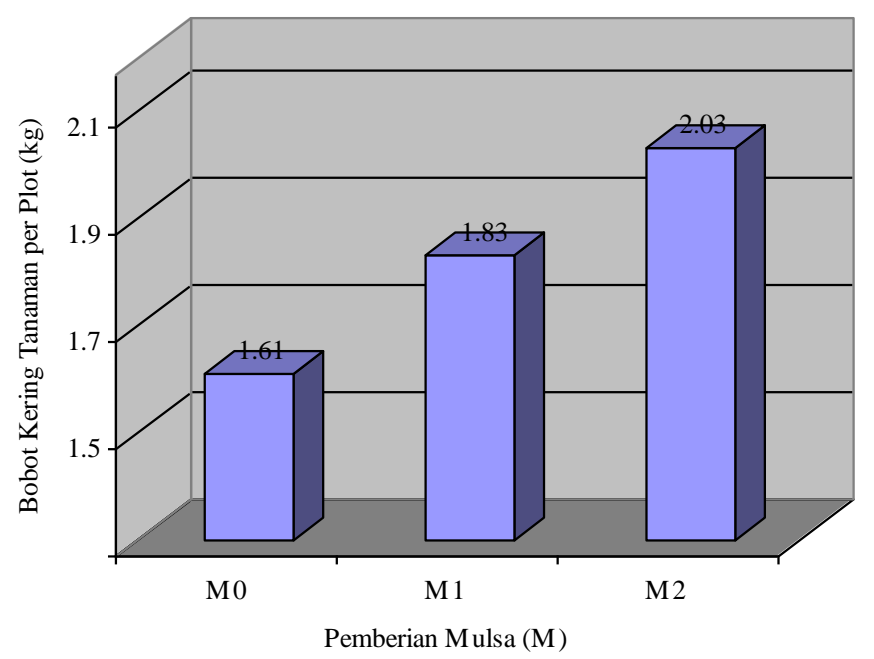

Gambar 12. Histogram Respon Pengaruh Pemberian Mulsa terhadap Bobot Kering Tanaman per Plot 
Dari Gambar 12 terlihat bahwa dengan pemberian mulsa $\left(\mathrm{M}_{1}\right.$ dan $\left.\mathrm{M}_{2}\right)$, bobot kering tanaman per plot lebih berat dibandingkan pada tanaman tanpa mulsa $\left(\mathrm{M}_{0}\right)$.

\subsubsection{Laju Tumbuh Relatif}

Rataan laju tumbuh relatif tanaman akibat perlakuan pupuk organik cair NASA dan pemberian mulsa disajikan pada Tabel 7 .

Tabel 7. Rataan Laju Tumbuh Relatif Tanaman (g/minggu) akibat Perlakuan Pupuk Organik Cair NASA dan Pemberian Mulsa

\begin{tabular}{ccccc}
\hline Perlakuan & $\mathrm{M}_{0}$ & $\mathrm{M}_{1}$ & $\mathrm{M}_{2}$ & Rataan \\
\hline $\mathrm{P}_{0}$ & 27.78 & 31.44 & 32.22 & 30.48 \\
$\mathrm{P}_{1}$ & 31.51 & 32.44 & 32.22 & 32.06 \\
$\mathrm{P}_{2}$ & 30.56 & 35.83 & 38.06 & 34.82 \\
\hline Rataan & 29.95 & 33.24 & 34.17 & \\
\hline
\end{tabular}

Keterangan: Angka yang diikuti oleh huruf yang sama dalam kolom dan baris perlakuan yang sama tidak berbeda nyata pada uji Duncan taraf uji 5\%

Tabel 7 menunjukkan bahwa laju tumbuh relatif antara taraf perlakuan dosis pupuk organik cair NASA berbeda tidak nyata.

Tabel 7 juga menunjukkan bahwa laju tumbuh relatif antara perlakuan mulsa berbeda tidak nyata.

\section{Pengaruh Pupuk Organik Cair} NASA terhadap Pertumbuhan dan Produksi Tanaman Peleng

Hasil sidik ragam menunjukkan bahwa perlakuan pupuk organik cair NASA berpengaruh nyata terhadap tinggi tanaman, jumlah daun, bobot segar tanaman per sampel, bobot segar tanaman per plot, bobot kering tanaman per sampel dan bobot kering tanaman per plot, tetapi berbeda tidak nyata terhadap laju tumbuh relatif tanaman.

Pemberian pupuk organik cair NASA dapat meningkatkan pertumbuhan tanaman. Hal ini disebabkan oleh komposisi pupuk organik cair tersebut mengandung berbagai unsur hara makro dan mikro yang lengkap, sehingga dengan pemberian pupuk tersebut dapat menyuplai kebutuhan unsur hara selama pertumbuhan. Pembentukan daun tanaman peleng dipengaruhi oleh besarnya fotosintesis yang terjadi selama pertumbuhan. Fotosintesis berlangsung dengan baik dengan tersedianya unsur hara (Sutejo, 1987). Pemberian pupuk organik cair NASA dapat memenuhi kebutuhan unsur hara selama pertumbuhan, karena mengandung berbagai unsur hara yang dapat digunakan tanaman selama proses pertumbuhannya.

Hasil penelitian menunjukkan bahwa peningkatan pemberian konsentrasi pupuk organik cair NASA dapat meningkatkan bobot segar tanaman dan bobot segar per plot. Hal ini dipengaruhi oleh tersedianya unsur hara selama pertumbuhan. Dalam pembentukan batang, daun dan akar tanaman dibutuhkan unsur hara makro dan mikro, sehingga pertumbuhan batang, daun dan akar yang diperoleh juga lebih baik (Novizan, 2005). Dengan penambahan pupuk organik cair NASA akan meningkatkan kebutuhan unsur hara oleh tanaman, sehingga pembentukan daun, batang dan akar tanaman menjadi lebih baik.

Hasil penelitian menunjukkan bahwa pemberian konsentrasi pupuk organik cair NASA sebesar $6 \mathrm{ml} / \mathrm{l}$ air memberikan hasil terbaik. Hal ini 
disebabkan pemberian pupuk organik cair NASA akan memberikan ketersediaan unsur hara selama pertumbuhan tanaman karena pupuk tersebut mengandung unsur hara lengkap (makro dan mikro), sehingga tanaman yang terdapat dalam satu areal pertanaman pertumbuhannya menjadi lebih seragam. Dengan demikian akan mempengaruhi produksi dalam satu plot tanam.

Menurut Lubis dkk., (1986) bahwa ketersediaan unsur hara yang tidak seimbang dan tidak lengkap, apalagi hanya nitrogen saja menyebabkan hilangnya unsur hara lain dalam tanah. Efek ketidakseimbangan hara tersebut terlihat dengan pertumbuhan tanaman yang kurang baik. Untuk menghasilkan tanaman dengan pertumbuhan yang baik maka dapat dilakukan pemupukan dengan mengikutsertakan unsur mikro dalam pemupukan adalah suatu upaya untuk mengatasi ketidakseimbangan unsur hara.

Menurut Suhaidi (2000) bahwa pemberian pupuk organik cair terhadap tanaman dapat memacu pertumbuhan tanaman, mempercepat intensitas kerja pupuk dan meningkatkan efisiensi penggunaan pupuk dan mempermudah aplikasi pupuk. Dengan kebutuhan unsur hara yang semakin terpenuhi akan semakin meningkatkan pertumbuhan tanaman secara merata pada setiap petak tanam. Pertumbuhan tanaman yang relatif seragam akan semakin meningkatkan produksi per petak.

Hasil penelitian menunjukkan bahwa pemberian pupuk organik cair NASA berpengaruh tidak nyata terhadap laju tumbuh relatif. Hal ini disebabkan pertumbuhan tanaman peleng kurang baik, sehingga pertumbuhannya tidak sesuai dengan deskripsi.

\section{Pengaruh Pemberian Mulsa terhadap Pertumbuhan dan Produksi Tanaman Peleng}

Hasil sidik ragam menunjukkan bahwa perlakuan pemberian mulsa berpengaruh nyata terhadap tinggi tanaman, jumlah daun, bobot segar tanaman per sampel, bobot segar tanaman per plot, bobot kering tanaman per sampel, bobot kering tanaman per plot, tetapi berpengaruh tidak nyata terhadap laju tumbuh relatif.

Hasil penelitian menunjukkan bahwa tanaman dengan mulsa organik dan mulsa hitam perak memiliki pertumbuhan dan produksi yang lebih baik dibandingkan dengan tanaman tanpa mulsa. Hal ini disebabkan dengan adanya mulsa dapat mencegah pemadatan tanah akibat air hujan. Disamping itu juga dapat menjaga temperatur dan kelembaban suhu yang stabil pada tanah. Menurut Triyono (2007), penggunaan mulsa dapat mempengaruhi kondisi fisik, kimia, dan biologis tanah. Pengaruh mulsa bagi sifat fisik tanah yaitu mengurangi dampak langsung butiran air hujan, mengurangi limpasan dan erosi, mengurangi pemadatan, mengurangi dampak erosi angin dan air, fluktuasi yang lebih kecil dalam kelembaban dan suhu tanah, memperbaiki struktur tanah, meningkatkan porositas, meningkatkan kapasitas menahan air, meningkatkan kapasitas infiltrasi, dan mengurangi penguapan. Sedangkan pengaruh biologis dari pemakaian mulsa yaitu dapat meningkatkan populasi serangga, termasuk cacing tanah dan hewan pengerat.

Menurut Sinukaban (1986) mulsa harus menutup permukaan tanah paling tidak sekitar $70-75 \%$. Jika mulsa menutupi tanah, maka mulsa ini akan sangat efektif mencegah proses pergerakan permukaan tanah, mencegah penyumbatan dan pemadatan tanah. 
Mulsa dapat digunakan baik pada tanah yang rusak maupun tanah yang sudah baik. Jika mulsa diberikan pada tanah yang rusak, maka mulsa akan memperbaiki sifat fisik, kimia dan biologis tanah tersebut, tetapi jika mulsa diberikan pada tanah yang kondisinya sudah baik, maka mulsa akan menjaga dan memelihara tanah tersebut sehingga dapat digunakan secara berkelanjutan.

Hasil penelitian menunjukkan bahwa pemberian mulsa hitam perak dan mulsa organik menghasilkan bobot segar per tanaman dan per plot yang lebih tinggi dibanding tanpa pemberian mulsa. Hal ini disebabkan dengan penggunaan mulsa dapat menurunkan suhu tanah pada siang hari. Menurut Mahmood et al., (2002) penurunan suhu tanah oleh mulsa disebabkan karena penggunaan mulsa dapat mengurangi radiasi yang diterima dan diserap oleh tanah sehingga dapat menurunkan suhu tanah pada siang hari. Dengan menurunkan suhu udara dan tanah dapat menekan kehilangan air dari permukaan tanah, sehingga mengurangi adanya cekaman kekeringan. Menurut Timlin et al., (2006) suhu tanah yang rendah dapat mengurangi laju respirasi akar sehingga asimilat yang dapat disumbangkan untuk penimbunan cadangan bahan makanan menjadi lebih banyak dibanding pada perlakuan tanpa mulsa.

\section{Interaksi antara Pupuk Organik Cair NASA dan Pemberian Mulsa terhadap Pertumbuhan dan Produksi Tanaman Peleng}

Hasil analisis sidik ragam menunjukkan bahwa interaksi antara pupuk organik cair NASA dan pemberian mulsa berpengaruh tidak nyata terhadap seluruh parameter yang diamati. Hal ini disebabkan kedua perlakuan tidak saling sinergis mendukung pertumhan tanaman, dimana pemberian pupuk organik cair diberikan pada daun tanaman, sehingga tidak didukung oleh pemberian mulsa yang lebih beperan melindungai tanah dari terpaan air hujan.

\section{KESIMPULAN dan SARAN Kesimpulan}

1. Perlakuan pupuk organik cair NASA hingga $6 \mathrm{ml} / \mathrm{l}$ air nyata meningkatkan tinggi tanaman, jumlah daun, bobot segar tanaman per sampel, bobot segar tanaman per plot, bobot kering tanaman per sampel dan bobot kering tanaman per plot, tetapi berbeda tidak nyata terhadap laju tumbuh relatif tanaman.

2. Perlakuan pemberian mulsa organik dan mulsa hitam perak nyata meningkatkan tinggi tanaman, jumlah daun, bobot segar tanaman per sampel, bobot segar tanaman per plot, bobot kering tanaman per sampel dan bobot kering tanaman per plot, tetapi berbeda tidak nyata terhadap laju tumbuh relatif tanaman.

3. Interaksi antara perlakuan pupuk organik cair NASA dan pemberian mulsa berpengaruh tidak nyata terhadap tinggi tanaman, jumlah daun, bobot segar tanaman per sampel, bobot segar tanaman per plot, bobot kering tanaman per sampel, bobot kering tanaman per plot dan laju tumbuh relatif tanaman.

\section{Saran}

1. Untuk meningkatkan pertumbuhan dan produksi tanaman peleng disarankan dengan menggunakan pemberian pupuk organik cair dengan dosis $6 \mathrm{ml} / \mathrm{l}$ air dengan pemberian mulsa organik atau mulsa hitam perak. 
2. Perlu penelitian lanjutan untuk mendapatkan produksi peleng yang optimal dengan meningkatkan dosis pupuk organik cair.

\section{DAFTAR PUSTAKA}

Hadisuwito, S. 2008. Membuat Pupuk Kompos Cair. PT Agromedia Pustaka. Jakarta.

Hakim, N, M. Yusuf Nyakpa, A. M. Lubis, S. G. Nugroho, M.R. Soul, M. Amin Dhina, Go Ban Hong dan H. H. Bailey. 1986. Dasar-dasar Ilmu Tanah. Fakultas Pertanian Universitas Lampung, Lampung.

Leafforlife. Org. 2005. Spinacia oleraceae. Spinach Espinaca. http://leafforlife.Org/PAGES/SP INACIA.HTM

Lubis, A. M., A. G. Amrah, M. A. Pulungan, M. Y. Nyakpa, dan N. Hakim. 1986. Pupuk dan Pemupukan. Jurusan Ilmu Tanah, Fakultas Pertanian, Universitas Isalam Sumatera Utara, Medan.

Mahmood, M., K. Farroq, A. Husain, R. Sher, 2002. Effect of Mulching on Growth and Yield of Potato Crop. Asian J. of Plant Sci. 1(2): $122-133$.

Mulyatri. 2003. Peranan pengolahan tanah dan bahan organik terhadap konservasi tanah dan air. Pros. Sem. Nas. Hasil-hasil Penelitian dan Pengkajian Teknologi Spesifik Lokasi.
Novizan, 2005. Petunjuk Pemupukan Yang Efektif. Agromedia Pustaka, Jakarta.

Sinukaban, N., and I W. S. Adnyana. 2007. Effect of vetiver grass strips and crop residue management systems on runoff, erosion, and soil productivity. In Soil and Water Conservation in Sustainable Development. Dirjen RLPS. Bogor. pp:13-25.

Suhaidi, T dan Lubis, L.M., 2000. Jurnal Ilmiah Pertanian Kultura. Fakultas Pertanian. Universitas Sumatera Utara. Medan.

Sutejo, M.M. 1987. Pupuk dan Cara Pemupukan. PT. Bina Aksara. Jakarta.

Timlin, D., S.M.L. Rahman, J. Baker, V.R Reddy, D. Feisher, B. Quebedeaux. 2006. Whole plant photosynthesis, development, and carbon partitioning in potato as a function of temperature. Agron. J. 98(5):1195-1203.

Triyono, K. 2007. Pengaruh sistem pengolahan tanah dan mulsa terhadap konservasi sumber daya tanah. Jurnal Inovasi Pertanian. Vol.6, No. 1 Hal. 1121. Jakarta.

Uga.S Edu. 2005. Spinach. Spinacia oleraceae http://www.Uga.edu/Vegetable/ Spinach. 